Environment, Biodiversity \& Soil Security
(EBSS)
http://jenvbs.journals.ekb.eg//

\title{
Mobility and Potential Ecological Risk Assessment of Copper and Zinc in Alluvial and Marine Soils in The North Nile Delta, Egypt
}

Heba Elbasiouny and Fathy Elbehiry

Biological and Environmental Sciences Department, Faculty of Home Economic, AlAzhar University, 31511, Egypt

Central Laboratory for Environmental Studies, Kafrelsheikh University,33516, Egypt.

\begin{abstract}
COPPER $(\mathrm{Cu})$ and zinc $(\mathrm{Zn})$ are micronutrients needed for organisms, however, they are heavy metals and may become toxic to the organisms when exceeding the allowable limit in the environment. Two soil types of marine and alluvial were sampled in the North Nile Delta, Egypt. Copper $(\mathrm{Cu})$ and zinc $(\mathrm{Zn})$ were analyzed to investigate the availability and to evaluate ecological risk assessment and identify pollution sources. $\mathrm{Cu}$ and $\mathrm{Zn}$ were extracted from soil samples by DTPA-TEA. The higher content of $\mathrm{Cu}$ was recorded in alluvial soil, especially in the surface, while Zn concentrations in both soils didn't differ with depth. Six indices were used in this study to evaluate the potential ecological risk of $\mathrm{Cu}$ and $\mathrm{Zn}$ in the examined soils. The results of these indices revealed that affecting $\mathrm{Cu}$ and $\mathrm{Zn}$ anthropogenically in some profiles of the studied soils. As well, the results of principal component analysis (PCA) showed that $\mathrm{Cu}$ and $\mathrm{Zn}$ in marine soils mainly originated from anthropogenic source, while this is true in alluvial soil in $\mathrm{Zn}$ only. Human and agricultural activities may be the main source of $\mathrm{Cu}$ and $\mathrm{Zn}$ especially fertilizers and pesticides, which indicates that there may be environmental threating by those metals in the study area in the future.
\end{abstract}

Keywords: Copper, Zinc, Mobility, Potential risk assessment, Nile Delta.

\section{Introduction}

Recently, environmental pollution is one of the major issuesthat threatenthe human health andsustainable development. Heavy metals (HMs) among many pollutantsand their ecological impacts haveattracted the grown attention from the academic and public because unlike other pollutants, HMsare toxic at low threshold concentrations, are generally refractory, persistent and can't be degraded or easily detoxified or removed biologically. In addition, they are accumulated biomagnificatedin living tissues and concentrated in several food chains and webs (Li et al., 2018; Rehman et al., 2018; Li et al. 2019; Xu et al., 2019; Jiang et al., 2020). The soil acts as a sink for metals and has been polluted anthropogenically by heavy metals at a growing rate consequent to intense urbanization and rapid industrialization. Solid waste disposal vehicular exhaust, fertilization, wastewater irrigation, and industrial activities (such as mining, metal melting andprocessing) all contribute to metals accumulation in the soil (Shi et al., 2018). In soil, HMs can degrade the quality of both soil and grain crops, as well, they cause great risks to the human health. For example, soil HMs accumulation can lead to destructing soil functions (then sustainability), as well, the deficiency of soil nutrients, whichconsequently influences the yield and quality of crops. Furthermore, HMs in soil mainly reach the human body through ingestion, inhalation, and skin contact, which may pose threats to anthropological health (DomokosSzabolcsy et al., 2017; Elbasiouny et al., 2017; Jiang et al., 2020).

Among the HMs, copper $(\mathrm{Cu})$ is special, as it

Corresponding author: fathyelbehiry@gmail.com

Received 13/12/2019; Accepted 31/12/2019

DOI: $10.21608 /$ jenvbs.2019.20947.1078

C2019 National Information and Documentation Center (NIDOC) 
is not only a micronutrient element for organisms, but also it is an environmental polluting and toxic element. Excessive $\mathrm{Cu}$ can extremely affect the plants' and animals'growth. Recently moreover, clinical medical research hasrevealed the incidence of cancer-related to increase in $\mathrm{Cu}$ concentration in the human serum (Li et al. 2019; Mičijević et al., 2020). Rahman et al. (2018) reported that $\mathrm{Cu}$ stimulates depression and finally lung cancer. Zinc $(\mathrm{Zn})$ also is an essential micronutrient in the soil and all living systems and has particular physiological functions (Alloway, 2008). The Zn,because of its concentration in the soil (10-300 ppm),can be counted as a trace element (TE) in soil (Lindsay, 1972). In common like other plant micronutrients, $\mathrm{Zn}$ can limit plant growth when it is present in excessive concentrations, as well as soil microorganisms affect by excessive and soil fauna (Alloway, 2008). The fate of several types of $\mathrm{Zn}$ is different and relies on its chemical properties in different soil types, and thus, it is hard to evaluate the overall level of $\mathrm{Zn}$ contamination (Mičijević et al., 2020). Agricultural practices, among other sources, are key sources of increasing $\mathrm{Cu}$ and $\mathrm{Zn}$ levels in surface soils (Kabata-Pendias, 2011).

Therefore, assessment and evaluating of HMs pollution in soil is very essential to be investigated(Rahman et al. 2018). Ecological risk assessment (ERA), in this context, is one of the effectiveapproaches to qualifying the ecological hazards of pollutants and forecasting the damaging effects of the contamination on ecological systems (Shi et al., 2018 and Xu et al., 2019).

Although, the Nile Delta is one of the eldest intensely cultivated regions on the Earth (Elbasiouny et al., 2017). There is alack of information about evaluating risk assessment of heavy metals, especially, those that have many advantages to plant and organisms in ecosystems such as $\mathrm{Cu}$ and $\mathrm{Zn}$. Therefore, this study aims to investigate the $\mathrm{Cu}$ and $\mathrm{Zn}$ mobility in two types of soils (i.e. alluvial and marine) in North Nile Delta, Egypt and their vertical distribution through soil profiles; and to evaluate the potential ecological risk of both metals in these soils.

\section{Martial and Methods}

\section{Investigation area}

The Egyptian Nile Delta Mediterranean coast is one of the greatest important estuaries in the Mediterranean Sea. The investigation area is located in Kafr Elsheikh Governorate the northern part of Nile Delta, Egypt. This Governorate is sited between longitudes $30^{\circ} 20^{\prime} \mathrm{E}$ and $31^{\circ} 20^{\prime} \mathrm{E}$ and latitudes $31^{\circ} 00^{\prime} \mathrm{N}$ and $31^{\circ} 40^{\prime} \mathrm{N}$. Alluvial plain presents $71.08 \%$ of physiographic soil units, while marine plain presents $9.57 \%$ of the total area. More details about the study area have been published in Elbehiry et al. (2017); Elbasiouny (2018); Elbehiry et al. (2019) and El-Ramady et al. (2019).

Sampling, preparation samples and its analysis

Soil samples were collected from 8 profiles, four soil profiles were collected from marine soil (P1, P2, P3, and P4) and four profiles from alluvial soil (P5, P6, P7, and P8 as in Fig. 1. The soil samples were collected in triplicates at three depths (i.e., 0-30, 30-60, and 60-100 cm) in each profile.The samples were composited, homogenized and air-dried, crushed, and sieved to $2 \mathrm{~mm}$. physiochemical analyses were accomplished on soil according to Sparks et al. (1996) as follows:

Soil $\mathrm{pH}$ was measured in 1:2.5 (soil: water) suspension. The Walkley-Black method was used to determine soil organic matter (SOM). Particle size distribution was performed by the pipette method. The available concentrations of $\mathrm{Fe}, \mathrm{Cu}$, and $\mathrm{Zn}$ were extracted by diethylene triamine pentaacetic acid-triethanol amine (DTPA-TEA). $1.967 \mathrm{~g}$ of DTPA was dissolved in distilled water (in a $500 \mathrm{ml}$ beaker), then $1.470 \mathrm{~g}$ of calcium chloride $\left(\mathrm{CaCl}_{2}\right)$ was weighed and added to the solution of DTPA. $14.91 \mathrm{~g}$ of TEA was added DTPA solution and volume was increased to $400 \mathrm{ml}$ with distilled water. $\mathrm{pH}$ was adjusted to 7.3 with $6 \mathrm{~N} \mathrm{HCl}$. The concentrations of $\mathrm{Fe}, \mathrm{Cu}$ and $\mathrm{Zn}$ were then measured by atomic absorption spectrometry (AAS) (GBC Avanta E, Victoria, Australia).

\section{Ecological risk assessment}

In this study, the metals content in the last soil layer $(60-100 \mathrm{~cm})$ was considered as a geochemical background of metals in the investigated soils (Mazurek et al., 2017). Using this way for a practical contamination assessment, it is may establish local baselines concentration by the average of many low concentration samples picked from the deep and least affected level of soil samples. Pollution indices, in this study, is quantified as the amount (or ratio) of metal enrichment in sample over the present concentrations in the reference material. Three indices were used for the environmental risk assessment as follows : 


\section{Enrichment factor (EF)}

The EF is a useful index to determine the anthropogenic degree of metal pollution (Chen et al. 2007; Aitta et al., 2019). The EF is calculated using equation 1 :

$$
\mathrm{EF}=\frac{\left(\frac{\text { Metal }}{\mathrm{Fe}}\right) \text { sample }}{\left(\frac{\text { Metal }}{\mathrm{Fe}}\right) \text { background }}
$$

EF is mainly used to find out the potential sources of pollution and the effect of human activities on soil contamination and human health. EF values were referred as suggested by Müller (1981)., where: $\mathrm{EF}<1$ : means there is no enrichment; $1<$ $\mathrm{EF}<3$ : indicates minor enrichment; $3<\mathrm{EF}<5$ : is moderate enrichment; $5<\mathrm{EF}<10$ meansrelatively severe enrichment; $10<\mathrm{EF}<25$ :indicates severe enrichment; $25<\mathrm{FE}<50$ : refers to highly severe enrichment; and $\mathrm{EF}>50$ : is extremely severe enrichment. Fe was used in Eq. 1 as a reference metal acts as a proxy for the soil clay content and as an acceptable normalization metal (Abrahimand Parker, 2008).

\section{Contaminant factor $(C F)$}

The $\mathrm{CF}$ is the ratio obtainedby dividing each metal concentration in the soil over the metal background value as described by Håkanson(1980) in Eq. 2.

$$
\mathrm{CF}=\frac{(\text { Metal) in sample }}{\text { (Metal)in background }}
$$

Where: CF higher than1:signifies to low contamination; $1<\mathrm{Cf}<3$ :suggests moderate contamination; $3<\mathrm{Cf}<6$ :means considerable contamination; and $\mathrm{Cf}>6$ :signs to very high contamination.

\section{Contamination degree (CD)}

The CD was calculated as the total CF for all samples (Eq. 3) as proposed by Håkanson (1980) in Eq. 3:

$$
\mathrm{CD}=\sum_{\mathrm{i}=2}^{\mathrm{i}-\mathrm{n}} \mathrm{CF}
$$

Where: CD lower than 6 indicates a low contamination degree; $6<\mathrm{CD}<12$ : is a moderate contamination degree; $12<\mathrm{CD}<24$ : refers to a highcontamination degree; and $\mathrm{CD}>24$ : reveals a very high contamination degree, pointing to serious anthropogenic pollution

\section{Geo-accumulation index (Igeo)}

The Igeo index estimates the natural variability in metal distribution and the anthropogenic effects (Zhang et al., 2018). This index can be calculated as described in Eq. 4:

$$
\text { Igeo }=\log 2[\mathrm{Cn} /(1.5 \times \mathrm{Bn})]
$$

Where: $\mathrm{Cn}$ is the concentration of (n) metal in the soil, while $\mathrm{Bn}$ is the value of geochemical background of this metal in the local soil parent material (Zhang et al., 2018). The level of pollution is divided into 7 grades, which range from no pollution to extremely strong pollution, according to the Igeo value. The seven classes of Igeo proposed by Müller (1969) are :

Class 0 : Igeo $\leq 0$ (uncontaminated);

Class 1: $0<$ Igeo $\leq 1$ (uncontaminated to moderately contaminated);

Class 2 : $1<$ lgeo $\leq 2$ (moderately contaminated); Class 3 : $2<$ Igeo $\leq 3$ (moderately to heavily contaminated);

Class 4: $4<$ Igeo $\leq 5$ (heavily to extremely contaminated); and

Class 6: Igeo > 5 (extremely contaminated) (Zhang et al., 2018).

\section{Potential ecological risk (PER)}

The PER also integrates factors of the PER of each metal together and relates their ecological and environmental impacts with their toxicity. This index is calculated by the following equation:

$$
\begin{aligned}
& \text { RI }=\sum_{\mathrm{i}-1}^{\mathrm{n}} \operatorname{Er}=\sum_{\mathrm{i}-1}^{\mathrm{n}} \operatorname{Tri} * \mathrm{Cfi} \\
& \text { PER }=\sum_{\mathbf{i}-1}^{\mathbf{m}} \text { Eri }
\end{aligned}
$$

Eq. 6

Eri is the ecological risk potential of each metal, and Tri is the toxic response coefficient. In this study, Tri values calculated by Hakanson (1980) were used, which were 5 and 1 for copper and zinc. The interpretive classifications of Eri index are: $<40$ low, 40-80 moderately, 80-160 considerable, $160-320$ high, $320<$ very high. PER index is a comprehensive PE indexpresenting the sum of Eri. The interpretive grades of PER are low which is higher than $150 ; 150$ to 300 is moderate; 300 to 600 is sever; and higher than 600 is serious (Suresh et al., 2012). 


\section{Statistical analysis}

Descriptive statistical analysis of $\mathrm{Cu}, \mathrm{Zn}$ and soil variables was performed with the software packages of SPSS statistics package 20 and with Microsoft Excel. Two-tailed Pearson correlation coefficient was applied to understand the correlations among available concentrations of $\mathrm{Cu}, \mathrm{Zn}$ and soil variables and to evaluate how well the sources and the route of $\mathrm{Cu}$ and $\mathrm{Zn}$ contamination if they correlated to each other. Principal component analysis (PCA) was used in the analysis of soil variables to determine the magnitude of these variables on $\mathrm{Cu}$ and $\mathrm{Zn}$.

\section{Results and Discussion}

The characteristics of studied soils

The soils differed in their physical and chemical properties as well as in their DTPAextractable $\mathrm{Fe}, \mathrm{Cu}$ and $\mathrm{Zn}$ concentrations (Table 1), and this reflects the diverse geological nature of the parent materials. Although both soils were alkaline. The soil $\mathrm{pH}$ in marine soil ranged from 8.05 to $8.62,7.91$ to 8.87 , and 8.06 to 8.75 in surface, subsurface and lower layers respectively, while in alluvial soil ranged from 7.88 to $8.21,8.02$ to 8.22 , and 7.91 to 8.27 in surface, subsurface and lower layers respectively (Table 1). The texture in marine soil was dominated by sandy, while alluvial soil was dominated by silt clay texture as described in Elbasiouny and Elbehiry (2019). The SOM in marine soil ranged from 0.3 to $6.7,0.2$ to 2.7 , and 1.7 to 2.9 $\mathrm{g} \mathrm{kg}^{-1}$ in surface, subsurface and lower layers, respectively, while in alluvial soil, it was higher and differed from 18.8 to $20.2,7.4$ to 30.6 , and 6.7 to $13.2 \mathrm{~g} \mathrm{~kg}^{-1}$ in surface, subsurface and lower layers, respectively. The mean DTPAextractable Fe ranged from 104.3 to $178.3 \mu \mathrm{g}$ $\mathrm{g}^{-1}$ in alluvial soil, while in marine soil ranged from 89.1 to $99.1 \mu \mathrm{g} \mathrm{g}^{-1}$ (Table 1). The data trends concentrating the values of soil properties, in case of positive skewness, in the right tail greater than the median, whereas the opposite is right in the negative skewness. The skewness can be ascribed to the extreme values in some soil properties (Chaminade, 2005 and Elbasiouny et al., 2014).

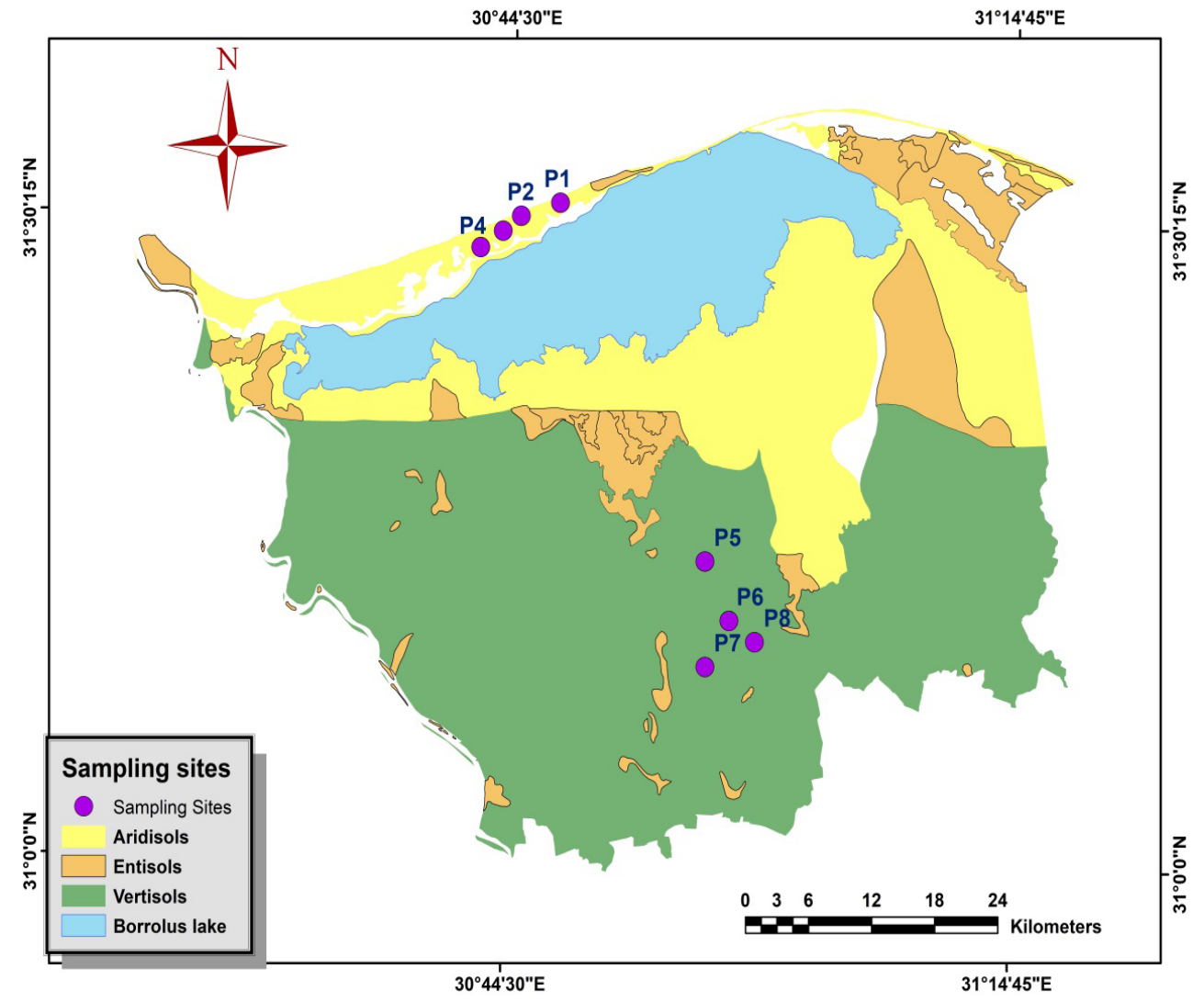

Fig.1. Samples location in Marin soil (P1, P2, P3, and P4) and Alluvial soils (P5, P6, P7, and P8) 
TABLE 1. Physiochemical characterizations and metal concentrations of the studied soils

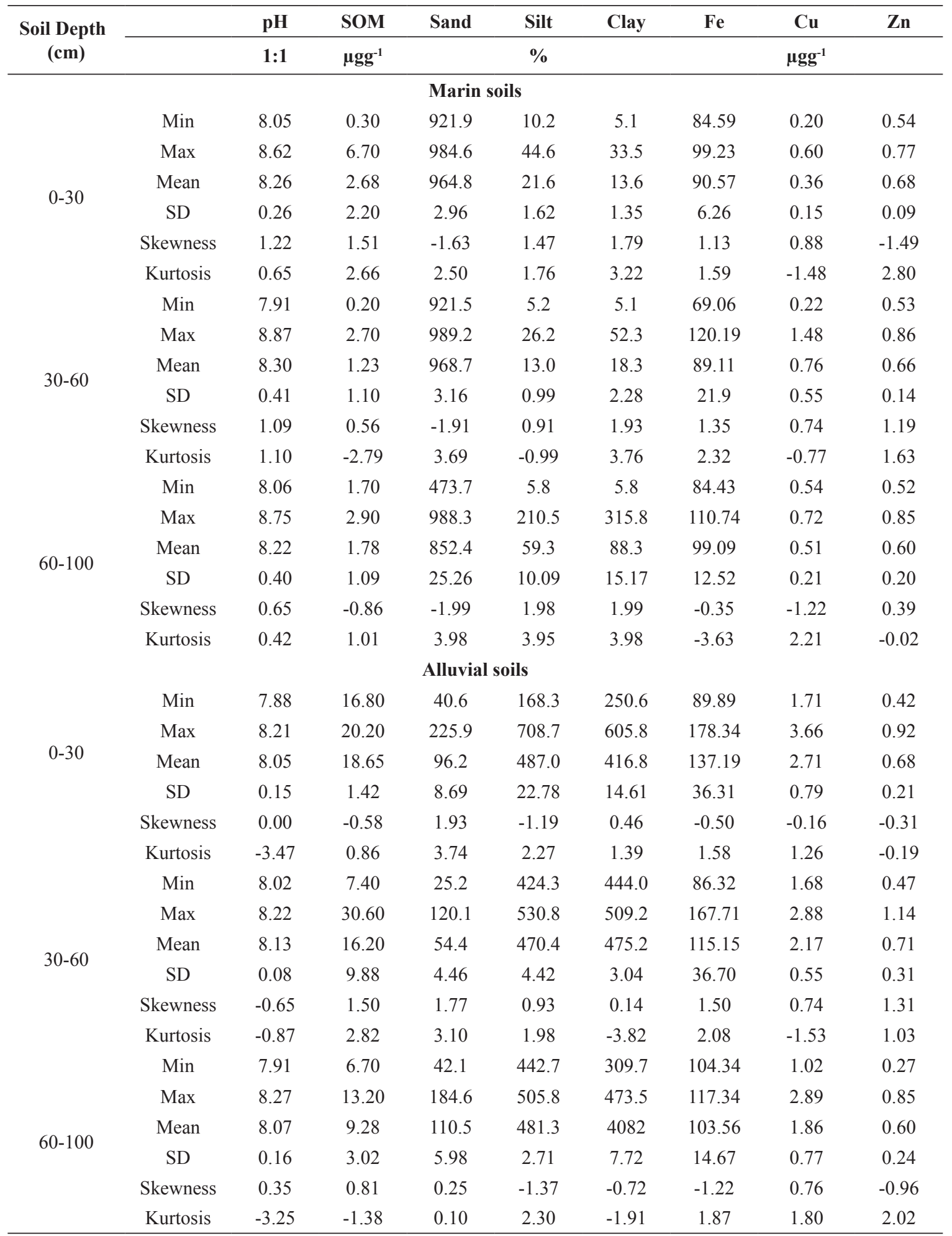


DTPA-TEA extractable $\mathrm{Cu}$ and $\mathrm{Zn}$ in soil and their vertical distribution

The DTPA-TEA $\mathrm{Cu}$ mean concentration values in marine soil represented $0.36,0.76$ and $2.71 \mu \mathrm{g} \mathrm{g}^{-1}$ in surface, subsurface and lower layers respectively. Whilst, the $\mathrm{Cu}$ mean concentration values in alluvial soil recorded 2.71. 2.17. and $1.86 \mu \mathrm{g} \mathrm{g}^{-1}$ in surface, subsurface and lower layers, respectively. According to Santos et al. (2013) the total concentrations of $\mathrm{Cu}$ and $\mathrm{Zn}$ in soil are a fair indicator of availability, however, they do not present conclusive information regarding the environmental impacts of this availability. Thus, the available $\mathrm{Cu}$ and $\mathrm{Zn}$ to the biota, if used as nutrients or toxic metals, in addition to their mobility are significant factors to care about when investigating the effects of these metals on the environment. Our mean $\mathrm{Cu}$ values are close to Niesiobedzka (2016) values in acid to mild alkaline soil, while their $\mathrm{Zn}$ values were higher than our values. DTPA, EDTA and acetic acid extractions are always used for studies about soil physicochemical processes such as trace metal mobility (Peijnenburg et al. 2007 and Niesiobedzka, 2016). The general view of vertical distribution of DTPA extractable soil $\mathrm{Cu}$ is the mean values increased with depth in marine soil, while it decreased with depth in alluvial soil. In details, it is indicated, from Fig. 2, that there is no clear trend of vertical distribution of DTPA extractable $\mathrm{Cu}$ on the level of each profile. Kabata-Pendias (2011) reported that important factors affecting the $\mathrm{Zn}$ mobilityin soil are very similar to factors listed for $\mathrm{Cu}$, however $\mathrm{Zn}$ seems to occur in more readily soluble forms.

The $\mathrm{Zn}$ mean concentration values in marine soil represented $0.68,0.66$ and $0.60 \mu \mathrm{g} \mathrm{g}^{-1}$ in surface, subsurface and lower layers, respectively. Whilst, the $\mathrm{Cu}$ mean concentration values in alluvial soil recorded 0.68. 0.71 and $0.60 \mu \mathrm{g} \mathrm{g}^{-1}$ in surface, subsurface and lower layers, respectively. It seems like the vertical distribution of mean values of DTPA extractable $\mathrm{Zn}$ is decreased with depth on the contrary of DTPA extractable $\mathrm{Cu}$ in marine soil, while in alluvial soil there is no clear trend. In details, it is indicated also, from Fig. 3, that there is no clear trend of the vertical distribution of DTPA extractable $\mathrm{Zn}$ on the level of each profile.

\section{Ecological risk assessment of $\mathrm{Cu}$ and $\mathrm{Zn}$ in the studied soils \\ Evaluation results of ERA indices for $\mathrm{Cu}$ and $\mathrm{Zn}$ are shown in Table 2. Ideally, EF values of $>1.5$}

Env. Biodiv. Soil Security Vol. 3 (2019) reveal that the metal is totally from crustal sources (i.e. a weathering product), whereas $\mathrm{EF}$ values of $<1.5$ is a sign of noncrustal sources contribution of metal (i.e. biota and/or pollution) (Zhang and Liu 2002; Chen et al. 2007 and Elbehiry et al., 2019). According to this statement and the values in Table 2, $\mathrm{Cu}$ is from crustal sources in marine soils, while in profiles 5 and 6 , in alluvial soil, the $\mathrm{Cu}$ came from noncrustal soil. EF values of $\mathrm{Zn}$ in marine soil indicated its noncrustal source in all profiles except profile 3 , while in alluvial soil, the same result of noncrustal source was observed in profiles 5 and 6. According to Sutherland (2000) and Elbehiry et al. (2019), where an EF of $>2$ indicates no to minor contamination. Thus, these results indicated that there are some profiles, either in marine or alluvial soil, are affected by anthropogenic sources of $\mathrm{Cu}$ and $\mathrm{Zn}$. Thus, attention should be paid to the environment in this area because this pollution may increase in the future.It is observed also that $\mathrm{EF}$ values of $\mathrm{Cu}$ are higher in alluvial soil than marine one, while the opposite is true in $\mathrm{Zn}$. This observation also was noticed in CF, Igeo and Tri values in both soils.

The CF values also showed low level or moderate contamination of $\mathrm{Cu}$ and $\mathrm{Zn}$ in the investigated profiles in sandy and clay soil, where the $\mathrm{CF}$ values are implied on the first and second categories of $\mathrm{CF}$ scale (i.e. $\mathrm{CF}<1$ represents a low level of contamination and $1 \leq \mathrm{CF}<3$ shows a moderate level of contamination) (Hakanson , 1980 and Elbehiry et al., 2019).

The contamination level of $\mathrm{Cu}$ and $\mathrm{Zn}$ (no to minor contamination), in both examined soils, is confirmed also by Igeo values that proposed by Müller (1969) and Zhang et al. (2018), where the values of Igeo recorded between $0<$ Igeo $\leq 1$, which indicate uncontaminated soil to moderately contaminated one (Class 1 of Igeo scale of 7 classes). This also in the same line with the previous result of EF.

The Eri results in Table 2 indicates also low contamination of extractable soil $\mathrm{Cu}$ and $\mathrm{Zn}$. Its mean value in $\mathrm{Cu}$ recorded 3.84 and 7.09 in marine and alluvial soil respectively. On the other side, its mean value in $\mathrm{Zn}$ represented 1.22 and 1.04 in marine and alluvial soil respectively.Eri and Igeoindices are used in the literature also to evaluate the ecotoxicological effect of pollutants on the organisms because of human activities (Naifar et al., 2018 and Arfaeinia et al., 2019). This can give a sign of utilizing and planning this area in the future. 

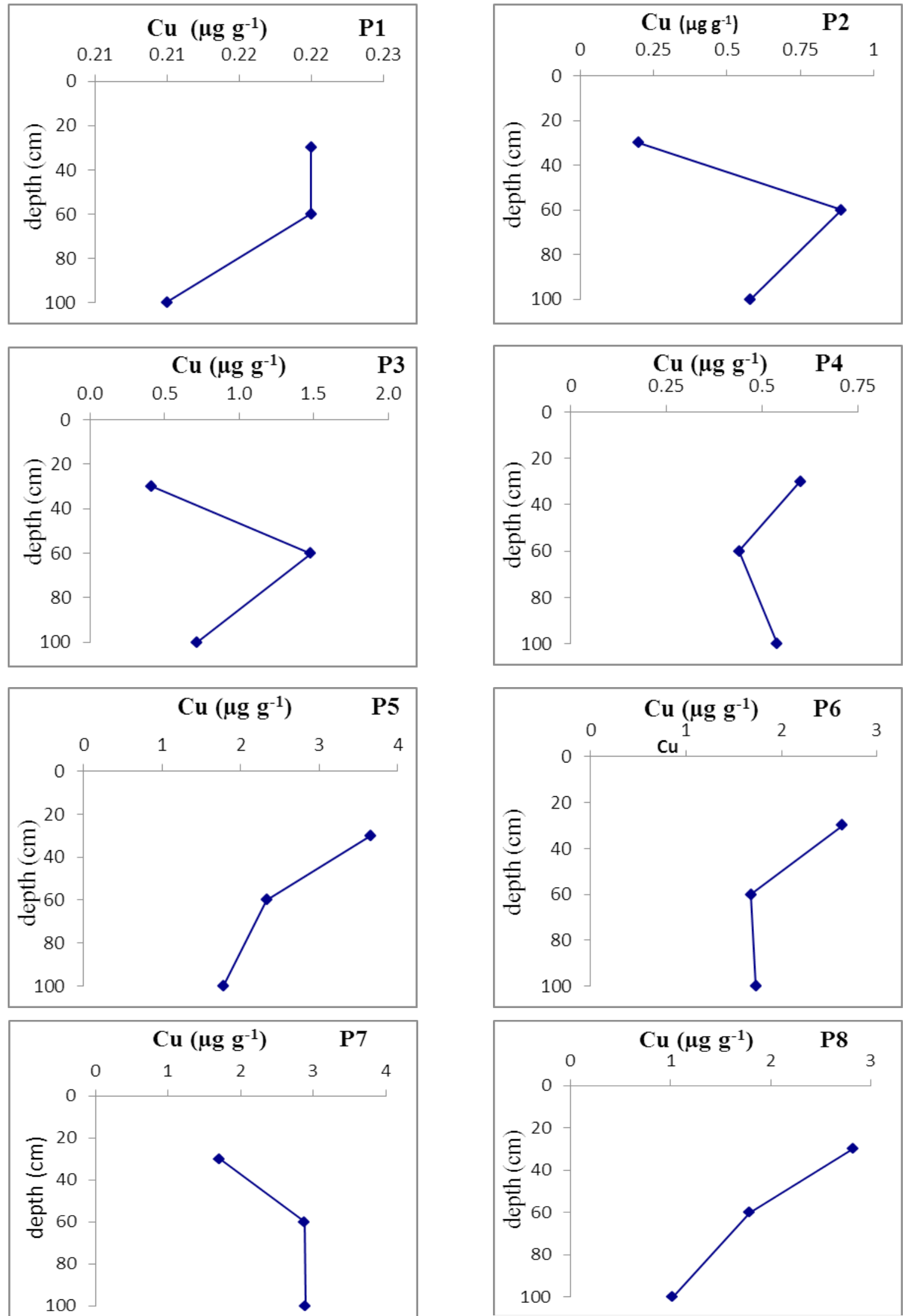

Fig. 2. Vertical distribution of $\mathrm{Cu}$ in marine (P1, P2, $\mathrm{P} 3$ and $\mathrm{P} 4)$ and alluvial (P5, P6, P7 and P8) soil profiles 

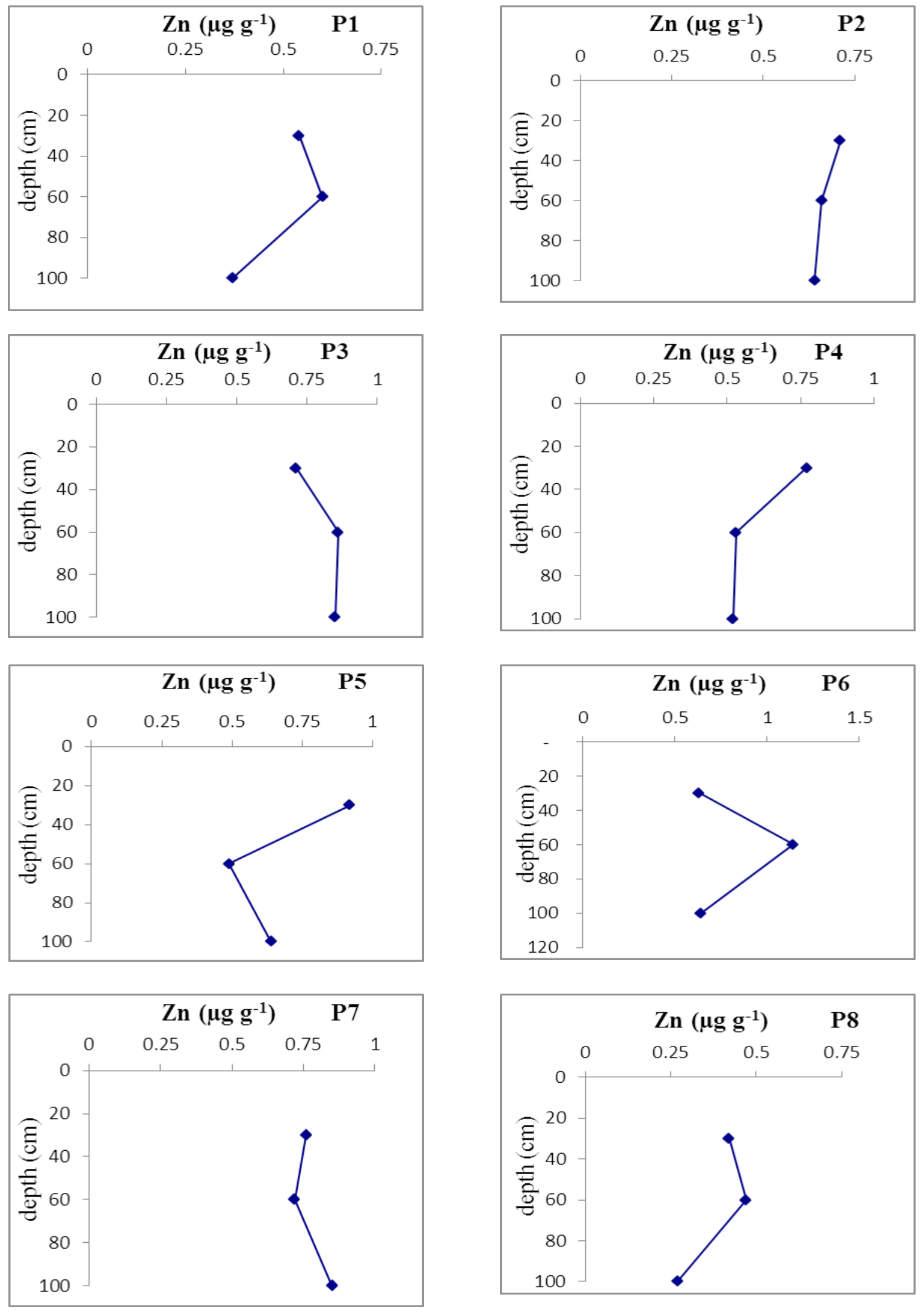

Fig. 3. Vertical distribution of $\mathrm{Zn}$ in marine (P1, P2, P3 and P4) and alluvial (P5, P6, P7 and P8) soil profiles Env. Biodiv. Soil Security Vol. 3 (2019) 
TABLE 2. Risk assessments for $\mathrm{Cu}$ and $\mathrm{Zn}$ usingenrichment factor (EF), geoaccumulation index (Igeo), contamination factor index (CF), and ecological risk assessmentof the studied soils

\begin{tabular}{|c|c|c|c|c|c|c|c|c|c|c|}
\hline \multirow{2}{*}{$\begin{array}{c}\text { Soil } \\
\text { profiles }\end{array}$} & \multicolumn{2}{|c|}{ EF } & \multicolumn{2}{|c|}{ Cf } & \multicolumn{2}{|c|}{ Igro } & \multicolumn{2}{|c|}{ Eri } & \multirow{2}{*}{ PER } & \multirow{2}{*}{ CD } \\
\hline & $\mathrm{Cu}$ & Zn & $\mathrm{Cu}$ & Zn & $\mathrm{Cu}$ & Zn & $\mathrm{Cu}$ & Zn & & \\
\hline \multicolumn{11}{|c|}{ Marin soils } \\
\hline $\mathrm{P} 2$ & 0.40 & 1.91 & 1.05 & 1.46 & 0.21 & 0.29 & 5.24 & 1.46 & 6.70 & 2.51 \\
\hline P3 & 0.19 & 1.17 & 0.34 & 1.11 & 0.07 & 0.22 & 1.72 & 1.11 & 2.83 & 1.45 \\
\hline $\mathrm{P} 4$ & 0.40 & 0.78 & 0.57 & 0.84 & 0.11 & 0.17 & 2.85 & 0.84 & 3.68 & 1.40 \\
\hline P9 & 0.54 & 1.61 & 1.11 & 1.48 & 0.22 & 0.30 & 5.56 & 1.48 & 7.04 & 2.59 \\
\hline \multirow{2}{*}{ Mean } & $0.38 \pm$ & $1.37 \pm$ & $0.77 \pm$ & $1.22 \pm$ & $0.15 \pm$ & $0.25 \pm$ & $3.84 \pm$ & $1.22 \pm$ & $5.06 \pm$ & $1.99 \pm$ \\
\hline & 0.15 & 0.50 & 0.37 & 0.31 & 0.07 & 0.06 & 1.86 & 0.31 & 2.12 & 0.65 \\
\hline \multicolumn{11}{|c|}{ Alluvial soils } \\
\hline $\mathrm{P} 10$ & 1.09 & 0.52 & 2.68 & 1.00 & 0.54 & 0.20 & 13.40 & 1.00 & 14.40 & 3.68 \\
\hline P11 & 1.56 & 1.14 & 1.53 & 0.98 & 0.31 & 0.20 & 7.63 & 0.98 & 8.61 & 2.51 \\
\hline P13 & 0.76 & 0.59 & 0.59 & 0.89 & 0.12 & 0.18 & 2.96 & 0.89 & 3.85 & 1.49 \\
\hline $\mathrm{P} 15$ & 0.81 & 0.98 & 0.87 & 1.27 & 0.18 & 0.25 & 4.37 & 1.27 & 5.64 & 2.14 \\
\hline Mean & $1.06 \pm$ & $0.81 \pm$ & $1.42 \pm$ & $1.04 \pm$ & $0.28 \pm$ & $0.21 \pm$ & $7.09 \pm$ & $1.04 \pm$ & $8.13 \pm$ & $2.46 \pm$ \\
\hline viean & 0.37 & 0.30 & 0.93 & 0.16 & 0.19 & 0.03 & 4.64 & 0.16 & 0.4 .26 & 0.92 \\
\hline
\end{tabular}

The mean value of PER recorded 5.06 in marine soil, while its corresponding mean value in alluvial soils recorded 8.13 According to Suresh et al. (2012), PER values reveals low potential ecological risk of $\mathrm{Cu}$ and $\mathrm{Zn}$ in both investigated soils. It signifies the sensitivity of a biological community to the toxic substances and explains the potential ecological risk produced from the overall contamination (Suresh et al., 2012).

The mean value of $\mathrm{CD}$ recorded 1.99 in marine soil, while its corresponding mean value in alluvial soils recorded 2.46. All values were lower than 6 indicating low contamination by $\mathrm{Cu}$ and $\mathrm{Zn}$ in the studied profiles.Elbehiry et al. (2019) indicated through their study on the whole Kafr Elsheikhgovernorate that $\mathrm{CD}$ values of selected metals signs to low (Mo and $\mathrm{V}$ ) or moderate ( $\mathrm{Sb}$ and $\mathrm{Sr}$ ) contamination in this area.

In general, soil HMs are either from natural source or from anthropogenic inputs. Natural source is associated with parent material, while anthropogenic inputs mainly result from industrial manufacture and discharge, coal combustion, vehicle emissions and agriculture activities and so on (Jiang et al., 2020). Our results and Elbehiry et al. (2019) indicate that human activities and management practices on this area are still not posing pressures by $\mathrm{Cu}$ and $\mathrm{Zn}$ on the environment. This could be considered in the future planning especially in the coastal degraded area in the Nile Delta, because any activities, that can present a pollution source in this area, may pose a threat to the environment. However, more studies are still required for more details especially spatial distribution studies.

\section{Correlation matrix and Principal Component} Analysis (PCA)

The results of correlation matrix revealed that $\mathrm{Cu}$ and $\mathrm{Zn}$ were insignificantly correlated, suggesting that these metals have different sources (Table 3). This result is in agreement with Kumar et al. (2019) who found insignificantly correlated between $\mathrm{Cu}$ and $\mathrm{Zn}$ in agriculture and urban soils. However, Suresh et al. (2012) observed the strongest positive correlation between $\mathrm{Cu}$ and $\mathrm{Zn}$. Suresh et al. (2012) studied the distribution of $\mathrm{Cu}$ and $\mathrm{Zn}$ among other metals is Veeranam Lake in India, which is different in its climate, in addition that the behavior of $\mathrm{Cu}$ and $\mathrm{Zn}$ may differ in the sediment than in the soil. The data in Table 3 also show that the major factors controlling $\mathrm{Cu}$ concentration in soils are $\mathrm{SOM}, \mathrm{Fe}$, silt and clay content which effectively influence mobility and solubility of $\mathrm{Cu}$ in the soil solution. According to Kabata-Pendias (2011), SOM is one of the most important factors affecting $\mathrm{Cu}$, as well $\mathrm{Zn}$, in the soil. The results in Table 3 also revealed that $\mathrm{Cu}$ 
was negatively correlated with sand $\left(R^{2}=-0.79\right)$. In this study also, insignificant difference was observed between $\mathrm{Zn}$ and other soil parameters (Table 3). Arfaeinia et al. (2019) who found insignificant difference between $\mathrm{Zn}$ and soil fractions (sand, silt and clay).

The PCA was performed to further assist the identification and analysis of sources of metals in soil. First, the results of Kaiser-MeyerOlkin $(\mathrm{KMO}>0.60)$ and significance Bartlett's phericity tests was $\mathrm{p}=0.001$, which generally indicated that the values were suitable for PCA. The achieved PCA involving loadings, eigen values and \%variance is given in Table 3 and Fig. 4. Eigen values greater than 1 are considered significant (Zhang et al., 2018). The PCA of marine soil indicates that $\mathrm{pH}$, sand, silt and clay excited in factor 1 and explained $45.5 \%$ of the total variance. Factor 2 accounted for $26.8 \%$ of the total variance and had strongly and positively related to $\mathrm{Cu}$ and $\mathrm{Zn}$. SOM contributed to factor 3 and explained $13.5 \%$ of the total variance. PCA of alluvial soil had positively related to $\mathrm{Cu}$ and $\mathrm{Zn}$ in factor 1 and accounted for $32.1 \%$ of the total variance. The $\mathrm{pH}$ and $\mathrm{Fe}$ contributed to factor 2 and explained $20.4 \%$ of the total variance, while factor 3 had maximum loadings on SOM and accounted for $17.2 \%$ of the total variance.

Several studies have proved that the association of $\mathrm{Cu}$ and $\mathrm{Zn}$ with the PCA can be indicated by the anthropogenic activities or diagenetic processes (Liu et al., 2015). Mico et al. (2006) and Jiang et al. (2020) also indicated that $\mathrm{Cu}$ and $\mathrm{Zn}$ are typically anthropogenic, and their compounds were mainly used in agricultural fertilizers and pesticides in addition to the productions from wastewater. Thus, PC factor 2 could be defined as anthropogenic component, especially agriculture. These results could be explained by the regional social and economic conditions of the study areas; where $\mathrm{Cu}$ and $\mathrm{Zn}$ are discharged basically from fertilizers and pesticides into the marine and alluvial area. This result is accorded with the previous results of ecological risk assessment indices, where the study area may be more polluted by $\mathrm{Cu}$ and $\mathrm{Zn}$ based on the human and agricultural activities.

\section{Conclusion}

This study provides data on the concentration level of extractable DTPA-TEA $\mathrm{Cu}$ and $\mathrm{Zn}$ in different marine and alluvial soil profiles with different depths. The available form of heavy metals is considered in many studies because it presentsconclusive information regarding the environmental impact of availability. The results showed that the mean concentration of $\mathrm{Cu}$ was higher in alluvial soil compared to marine soil specially in surface depth. The mean values of $\mathrm{Cu}$ (on the contrary of $\mathrm{Zn}$ ) seems to increase with depth in marine soil. Evaluating potential ecological risk revealed that the contamination level of $\mathrm{Cu}$ and $\mathrm{Zn}$ in the studied soils was low to moderate indicating that human and agricultural activities are relatively responsible for pollution by those metals in this area. According to this study, the attention should be paid to the performed activities in the North Nile Delta, Egypt, because it may be a source of pollution by both metals in the future.

TABLE 3. Pearson's correlation coefficients between $\mathrm{Cu}, \mathrm{Zn}$ and soil properties of samples collected from marine and alluvial soils

\begin{tabular}{ccccccccc}
\hline & $\mathbf{C u}$ & $\mathbf{Z n}$ & $\mathbf{F e}$ & $\mathbf{S O M}$ & $\mathbf{p H}$ & Sand & Silt & Clay \\
\hline $\mathrm{Cu}$ & 1 & & & & & & & \\
$\mathrm{Zn}$ & 0.25 & 1 & & & & & \\
$\mathrm{Fe}$ & $0.68^{* *}$ & 0.19 & 1 & & & & \\
$\mathrm{SOM}$ & $0.75^{* *}$ & 0.07 & $0.52^{* *}$ & 1 & & & \\
$\mathrm{pH}$ & -0.22 & -0.25 & -0.18 & $-0.30^{*}$ & 1 & & & \\
$\mathrm{Sand}$ & $-0.79^{* *}$ & 0.01 & $-0.58^{* *}$ & $-0.71^{* *}$ & 0.18 & 1 & & \\
Silt & $0.72^{* *}$ & 0.03 & $0.61^{* *}$ & $0.64^{* *}$ & -0.15 & $-0.95^{* *}$ & 1 \\
Clay & $0.46^{*}$ & -0.06 & $0.45^{*}$ & $0.70^{* *}$ & -0.18 & $-0.91^{* *}$ & $0.74^{* *}$ & 1 \\
\hline
\end{tabular}

*Correlation is significant at p b 0.05 (two-tailed).

${ }^{* *}$ Correlation is significant at p b 0.01 (two-tailed). 
A

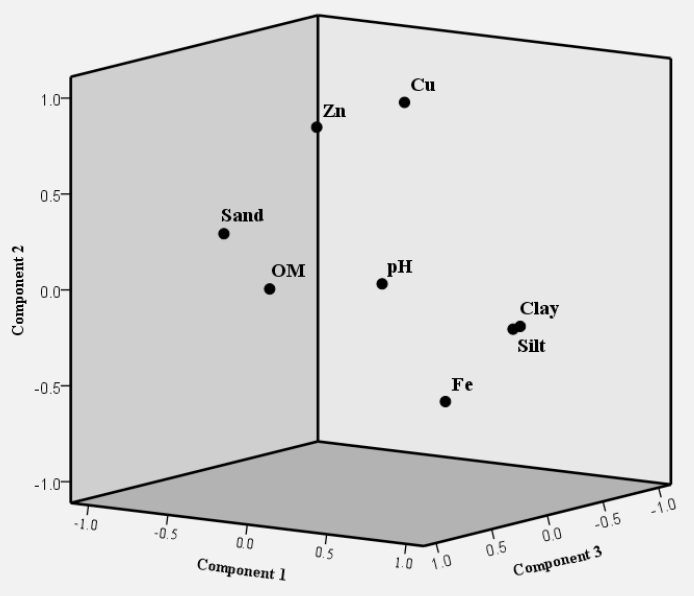

B

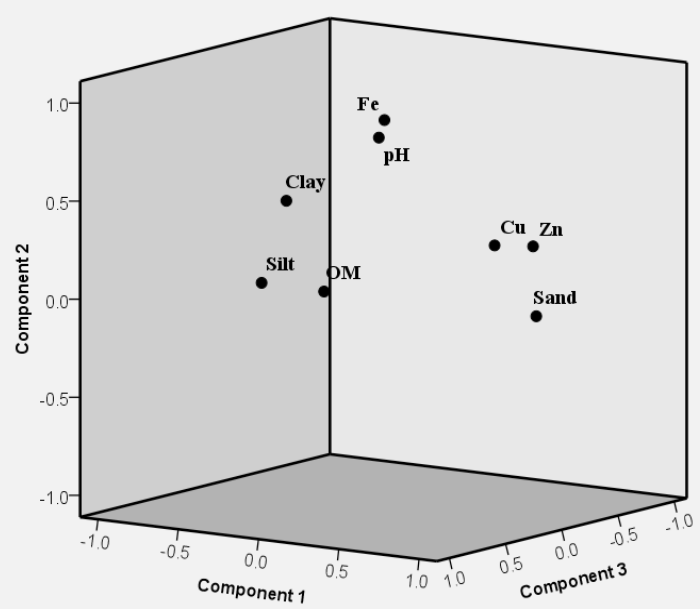

Fig. 4. PCA loading plot of metals and soil properties in marine (A) and alluvial (B) soil profiles 
TABLE 4. Total variance explained and rotated component matrix (four principal components selected) for soil properties, $\mathrm{Cu}$ and $\mathrm{Zn}$

\begin{tabular}{|c|c|c|c|c|c|c|}
\hline \multirow{2}{*}{ Variables } & \multicolumn{3}{|c|}{ Initial Eigenvalues } & \multicolumn{3}{|c|}{ Rotated Component Matrix } \\
\hline & Total & Variance $\%$ & Cumulative \% & PC1 & PC2 & PC3 \\
\hline \multicolumn{7}{|c|}{ Marin soil } \\
\hline $\mathrm{pH}$ & 3.64 & 45.52 & 45.52 & 0.57 & 0.15 & 0.72 \\
\hline $\mathrm{OM}$ & 2.15 & 26.87 & 72.40 & 0.01 & 0.09 & 0.93 \\
\hline $\mathrm{Fe}$ & 1.08 & 13.52 & 85.92 & 0.29 & -0.63 & -0.25 \\
\hline Sand & 0.75 & 9.35 & 95.27 & -0.98 & 0.13 & -0.08 \\
\hline Silt & 0.26 & 3.29 & 98.57 & 0.97 & -0.14 & 0.11 \\
\hline Clay & 0.11 & 1.37 & 99.95 & 0.98 & -0.13 & 0.06 \\
\hline $\mathrm{Cu}$ & 0.01 & 0.04 & 100.00 & 0.13 & 0.92 & -0.11 \\
\hline $\mathrm{Zn}$ & $3.11 \mathrm{E}-8$ & $3.89 \mathrm{E}-7$ & 100.000 & -0.22 & 0.80 & 0.17 \\
\hline \multicolumn{7}{|c|}{ Alluvial soil } \\
\hline $\mathrm{pH}$ & 2.57 & 32.14 & 32.14 & -0.04 & 0.77 & -0.01 \\
\hline OM & 1.63 & 20.43 & 52.57 & 0.23 & 0.14 & 0.87 \\
\hline $\mathrm{Fe}$ & 1.37 & 17.20 & 69.77 & 0.03 & 0.87 & 0.04 \\
\hline Sand & 0.89 & 11.17 & 80.94 & 0.89 & -0.05 & -0.08 \\
\hline Silt & 0.70 & 8.77 & 89.71 & -0.66 & -0.01 & 0.13 \\
\hline Clay & 0.41 & 5.11 & 94.83 & -0.71 & 0.36 & -0.15 \\
\hline $\mathrm{Cu}$ & 0.30 & 3.73 & 98.56 & 0.77 & 0.32 & 0.10 \\
\hline $\mathrm{Zn}$ & 0.11 & 1.43 & 100.00 & 0.41 & 0.15 & -0.75 \\
\hline
\end{tabular}

\section{References}

Abrahim, G.M.S., Parker, R.J. (2008). Assessment of heavy metal enrichment factors and the degree of contamination in marine sediments from Tamaki Estuary, Auckland, New Zealand. Environ Monit Assess, 136, 227-238 DOI 10.1007/s10661-0079678-2.

Aitta, A., El-Ramady, H., Alshaal, T., El-Henawy, A., Shams, M., Talha, N., Elbehiry, F., Brevik, E. (2019). Ecological risk assessment and spatial distribution of soil trace elements around Kitchener drain in the Northern Nile Delta, Egypt. Agriculture, 9, 152. https: //doi.org/10.3390/ agriculture 9070152.

Alloway, B.J. (2008). Zinc in Soils and Crop Nutrition. Second edition IZA and IFA Brussels, Belgium and Paris, France. 135 pp.

Arfaeinia, H., Dobaradaran, S., Moradi, M., Pasalari,
H., Mehrizi, E. A., Taghizadeh, F., Esmaili, A., Ansarizadeh, M. (2019) The effect of land use configurations on concentration, spatial distribution, and ecological risk of heavy metals in coastal sediments of northern part along the Persian Gulf. Science of the Total Environment, 653, 783-791. https://doi.org/10.1016/j.scitotenv.2018.11.009

Chen, C.W., Kao, C.M., Chen, C.F., Dong, C. D. (2007). Distribution and accumulation of heavy metals in the sediments of Kaohsiung Harbor, Taiwan. Chemosphere, 66 (8), 1431-1440. https:// doi.org/10.1016/j.chemosphere.2006.09.030.

Chaminade, G., 2005. Topography, soil carbon-nitrogen ratio and vegetation in boreal coniferous forests at the landscape level. A Master of Science Thesis in Soil Sciences at the Department of Forest Soils at the Swedish University of Agricultural Sciences.

Elbasiouny, H. (2018) Assessment of Environmental Sensitivity to Desertification, Soil Quality and 
Sustainability in An Area of The North Nile Delta, Egypt. Egypt. J. Soil. Sci. 58 (4), 399-415. DOI: 10.21608/ejss.2018.4741.1192

Elbasiouny, H. and Elbehiry, F. (2019) Geology. H. El-Ramady et al. (Ed.), The Soils of Egypt, World Soils Book Series, https://doi.org/10.1007/978-3319-95516-2 6. (C) Springer Nature Switzerland AG 2019.

Elbehiry, F., Elbasiouny, H., Elhenawy, A. (2017). Boron: Spatial distribution in an area of North Nile Delta, Egypt. Communications in Soil Science and Plant Analysis, 48, 3, 294-306, DOI: 10.1080/00103624.2016.1269795.

Elbehiry, F., Elbasiouny, H., Abowaly, M., (2017).Soil quality- special focus on salt-affected soils: review and case study in Egypt. Environment, Biodiversity and Soil Security, 1, 85-100. DOI: 10.21608/ jenvbs.2017.1085.1005

Elbasiouny, H., Abowaly, M., Abu_Alkheir, A., Gad, A., Elbehiry, F. (2017). Restoration and sequestration of carbon and nitrogen in degraded northern coastal area in Nile Delta, Egypt for climate change mitigation. Journal of Coastal conservation, 21, 105-114, DOI: 10.1007/s11852-016-0475-3.

Elbehiry, F., Elbasiouny, H., El-Ramady, H., Brevik, E.C. (2019). Mobility, distribution, and potential risk assessment of selected trace elements in soils of the Nile Delta, Egypt. Environ Monit Assess (2019) 191:713. https://doi.org/10.1007/s10661019-7892-3.

El-ramady, H., Abowaly, M., Elbehiry, F., Omara, A., Elsakhawy, T., Mohamed, E.S., Belal, A., Elbasiouny, H., Fawzy, Z.F. (2019). Stressful Environments and Sustainable Soil Management: A Case Study of Kafr El-Sheikh, Egypt. Env. Biodiv. Soil Security, 3, 193 - 213. DOI: 10.21608/ jenvbs.2019.17750.1070

Hakanson, L. (1980). An ecological risk index for aquatic pollutioncontrol-a sedimentological approach. Water Research, 14, 975-1001. https:// doi.org/10.1016/0043-1354(80)90143-8.

Domokos-Szabolcsy, E., Alshaal, T., Elhawat, N., Abdalla, N., dos Reis, A.R.; El-Ramady, H. (2017). The Interactions between Selenium, Nutrients and Heavy Metals in Higher Plants under Abiotic Stresses. Env. Biodiv. Soil Security, 1, 5- 31. DOI: 10.21608/jenvbs.2017.951.1001

Jiang, H., Cai, L., Wen, H., Hu, G., Chen, L., Luo, J. (2020) An integrated approach to quantifying ecological and human health risks from different sources of soil heavy metals. Science of the Total Environment, 701 (2020) 134466. https://doi. org/10.1016/j.scitotenv.2019.134466.

Kabata-Pendias, A. (2011) Trace Elements in Soils and Plants (4th ed.). Boca Raton: CRC.

Kumar, V, Sharma, A., Kaur, P., Sidhu, G., Bali, A., Bhardwaj, R., Thukral, A., Cerda, A. (2019). Pollution assessment of heavy metals in soils of India and ecological risk assessment: A state-ofthe-art. Chemosphere, 216, 449-462.

Li, L., Wu, J., Lu, J., Min, X., Xu, J., Yang, L. (2018) Distribution, pollution, bioaccumulation, and ecological risks of trace elements in soils of the northeastern Qinghai-Tibet Plateau. Ecotoxicology and Environmental Safety, 166, 345-353. https:// doi.org/10.1016/j.ecoenv.2018.09.110

Li, X., Zhang, J., Gong, Y., Liu, Q., Yang, S., Ma, J., Zhao, L., Hou, H. (2019). Statusof copper accumulation in agricultural soils across China (1985-2016), Chemosphere, doi:https://doi. org/10.1016/j.chemosphere.2019.125516.

Lindsay, W. L. (1972) Zinc in Soils and Plant Nutrition. Advances in Agronomy, 24, 147-186.

Liu, J Ma, K, Qu,L. (2015). Ecological risk assessments and context-dependence analysis of heavy metal contamination in the sediments of mangrove swamp in Leizhou Peninsula, China. Marine Pollution Bulletin, 100, 224-230. http://dx.doi.org/10.1016/j. marpolbul.2015.08.046

Mičijević, A., Šukalić, A., Leto, A. (2020) Noncancerogenic Risk to Human Health with $\mathrm{Pb}, \mathrm{Cu}$, and $\mathrm{Zn}$ Intake from Soil in the Area of Herzegovina. In: I. Karabegović (Ed.): NT 2019, LNNS 76, pp. 663-671, 2020. https://doi.org/10.1007/978-3030-18072-0_78. Springer Nature Switzerland AG 2020.

Mico, C., Recatala, L., Peris, M., Sanchez, J., 2006. Assessing heavy metal sources in agricultural soils of an European Mediterranean area by multivariate analysis. Chemosphere, 65, 863-872.

Mazurek, R., Kowalska, J., Gasiorek, M., Zadrozny, P., Jozefowska, A., Zaleski, T., Kepka, W., MarylaTymczuk, M., Orłowska, K. (2017) Assessment of heavy metals contamination in surface layers of Roztocze National Park forest soils (SE Poland) by indices of pollution. Chemosphere, 168, 839-850. https://doi.org/10.1016/j. chemosphere. 2016.10.126.

Env. Biodiv. Soil Security Vol. 3 (2019) 
Müller, G. (1969) Index of geoaccumulation in sediments of the Rhine River. Geol. J. 2, 108-118.

Naifar, I., Pereira, F., Zmemla, R., Bouaziz, M., et al. (2018) Spatial distribution and contamination assessment of heavy metals in marine sediments of the southern coast of Sfax, Gabes Gulf, Tunisia. Mar. Pollut. Bull. 131, 53-62.

Niesiobedzka, K. Environ Earth Sci (2016) Mobile forms and migration ability of $\mathrm{Cu}, \mathrm{Pb}$ and $\mathrm{Zn}$ in forestry system in Poland. Environmental Earth Sciences, 75, 122. https://doi.org/10.1007/s12665015-4821-9.

Peijnenburg WJG, Zablotskaja M, Vijver MG (2007) Monitoring metals in terrestrial environments within a bioavailability and focus on soil extraction. Ecotoxicol Environ Saf, 67, 163-179.

Rehman, I., Ishaq, M, Ali, L., Khan, S., Ahmad, I., Din, I.U., Ullah, H. (2018). risk assessment via toxic metals in soil and surface water ingestion in the vicinity of Sewakht mines, district Chitral, Northern Pakistan. Ecotoxicology and Environmental Safety, 154 (2018) 127-136. https://doi.org/10.1016/j. ecoenv.2018.02.033.

Santos, G.C.G., Valladares, G.S., Abreu, C.A., Camargo, O.A., Grego, C.R. (2013) Assessment of Copper and Zinc in Soils of a Vineyard Region in the State of São Paulo, Brazil: Applied and Environmental Soil Science, vol. 2013, Article ID 790795, 10 pages, 2013. https://doi.org/10.1155/2013/790795.

Shi, Y., Xu, X., Li, Q., Zhang, M., Li, J., Lu, Y., Liang, R., Zheng, X., Shao, X. (2018) Integrated regional ecological risk assessment of multiple metals in the soils: A case in the region around the Bohai Sea and the Yellow Sea. Environnemental Pollution, 242 (2018) 288-297. https://doi.org/10.1016/j. envpol.2018.06.058.
Sparks, D. L., Page, A. L., Helmke, P. A., Loppert, R. H., Soltanpour, P. N., Tabatabai, M. A., Johnston, C. T., Summner, M. E. (1996) Methods of soil analysis: chemical methods, Part 3. Madison, WI: Agronomy Society of America and Soil Science Society of America.

Suresh, G., Sutharsan, P., Ramasamy, V., Venkata chalapathy, R. (2012) Assessment of spatialdis tribution and potentialecolo gicalrisk of the heavy metalsinrelationto granulometric contents of Veeranam lake sediments,India. Ecotoxicology and Environmental Safety, 84, 117-124. http://dx.doi. org/10.1016/j.ecoenv.2012.06.027.

Sutherland, R. A. (2000) Bed sediment-associated trace metals in an urban stream, Oahu, Hawaii. Environmental Geology, 39 (6), 611-627. https:// doi.org/10.1007/s002540050473.

Xu, X., Wang, T., Sun, M., Bai, Y., Fu, C., Zhang, L., $\mathrm{Hu}$, X., Hagist, S. (2019) Management principles for heavy metal contaminated farmland based on ecological risk-A case study in the pilot area of Hunan province, China. Science of the Total Environment, 684, 537-547. https://doi. org/10.1016/j.scitotenv.2019.05.015

Zhang, J. and Liu, C. L. (2002) Riverine composition and estuarine geochemistry of particulate metals in China-weathering features, anthropogenic impact and chemical fluxes. Estuarine, Coastal and Shelf Science, 54 (6), 1051-1070. https://doi. org/10.1006/ecss.2001.0879.

Zhang P; Qinc C; Hong X; Kang G; Qin M; Yang D; Pang B; Li Y; He J; Dick RP (2018) Risk assessment and source analysis of soil heavy metal pollution from lower reaches of Yellow River irrigation in China. Science of the Total Environment, 633, 1136-1147. https://doi.org/10.1016/j.scitotenv.2018.03.228 